\title{
Digestibilidade e Degradabilidade de Rações à Base de Milho Desintegrado com Palha e Sabugo em Diferentes Graus de Moagem ${ }^{1}$
}

\author{
Solidete de Fátima Paziani ${ }^{2}$, Telma Teresinha Berchielli ${ }^{3,4}$, Pedro de Andrade ${ }^{3}$
}

RESUMO - O objetivo deste trabalho foi determinar a digestibilidade, usando óxido crômico $\left(\mathrm{Cr}_{2} \mathrm{O}_{3}\right)$ e FDN indigestível, como indicadores, e a degradação de dietas compostas de milho desintegrado com palha e sabugo (MDPS) em três graus de moagem (3/8, 9/16 e 3/4 de polegadas) e duas fontes protéicas, o farelo de amendoim e o glúten de milho-20, em um experimento fatorial com seis tratamentos. Os graus de moagem de MDPS e as fontes protéicas não tiveram efeito sobre $\mathrm{pH}$, concentração de amônia ruminal, digestibilidade das rações (matéria seca - MS, proteína bruta - PB, extrato etéreo - EE, amido, fibra em detergente neutro - FDN e fibra em detergente ácido - FDA) e degradação ruminal de matéria seca e amido. Os coeficientes de digestibilidade para todos os nutrientes diferiram entre os dois indicadores, sendo maiores para o $\mathrm{Cr}_{2} \mathrm{O}_{3}$. Houve interação significativa entre fonte protéica e graus de moagem do MDPS para pH e amônia, somente para a moagem 9/16 polegadas, com menor $\mathrm{pH}$ ocorrendo com o farelo de amendoim e a menor concentração de amônia com o glúten de milho-20. Para a degradação ruminal da MS não houve efeito de grau de moagem de MDPS, mas houve efeito de fonte protéica, com degradação efetiva maior com o uso do glúten de milho-20. Quanto à degradação ruminal de amido do MDPS incubado com o concentrado protéico, não houve diferença entre as fontes protéicas, mas, ao se incubar somente o MDPS, a degradação do amido foi maior em animais que estavam recebendo glúten de milho-20.

Palavras-chave: amido, farelo de amendoim, FDN indigestível, glúten de milho-20, óxido crômico

\section{Digestibility and Degradability of Diets with Different Milling Degrees Ground Ear Corn}

ABSTRACT - This work was carried out to evaluate the digestibility, using $\mathrm{Cr}_{2} \mathrm{O}_{3}$ and indigestible neutral detergent fiber (INDF), as markers, and also the degradability using ground ear corn (GEC). Six treatments were used in a factorial design, with three milling degrees (3/8", 9/16" and 3/4") of ground ear corn and peanut meal or corn gluten feed as protein sources. The milling degrees of ground ear corn did not have effect on $\mathrm{pH}, \mathrm{N}-\mathrm{NH}_{3}$, digestibility (dry matter - DM, crude protein - CP, extract ether extract - EE, starch, neutral detergent fiber - NDF, acid detergent fiber - ADF) and ruminal degradability for DM and starch. Digestibility coefficients differed between two markers and were higher for $\mathrm{Cr}_{2} \mathrm{O}_{3}$. There was significant interaction for $\mathrm{pH}$ and $\mathrm{N}-\mathrm{NH}_{3}$ between protein sources and milling degree, but only on 9/16", with lowest $\mathrm{pH}$ value for peanut meal and lowest $\mathrm{N}-\mathrm{NH}_{3}$ concentration for corn gluten feed. There was no effect of milling degree on rumen degradability of dry matter, but there was protein sources effect, and the degradability was higher on corn gluten feed treatments. The starch degradability of GEC plus protein source did not differ between protein sources, but differed when only GEC on nylon bags was used, the starch degradability was higher in corn gluten feed treatments.

Key Words: chromic oxide, corn gluten feed, indigestible NDF, peanut meal, starch

\section{Introdução}

Entre os grãos produzidos no Brasil, o milho é o mais usado para compor rações, como fonte energética, associado a fontes protéicas e volumosos, geralmente cana ou silagem. Entretanto, como a mecanização é uma atividade que eleva os custos, é uma incoerência que durante a colheita do milho grão se desprezem a palha e o sabugo e, posteriormente, ao ter que compor rações, mobilizem-se novamente máquinas para a colheita e processamento de um volumoso.
O uso da espiga inteira, na forma de milho desintegrado com palha e sabugo (MDPS), pode ser de muita utilidade na nutrição de ruminantes, especialmente em algumas regiões ou países, que, em certas épocas do ano ocorre deficiência de alimentos; desde que se avalie a sua forma de uso, como por exemplo, associação com concentrados ou volumosos, bem como o grau de moagem.

A moagem de grãos é um procedimento muito adotado, pois espera-se obter maior aproveitamento do alimento no processo digestivo, mas isto nem

\footnotetext{
${ }^{1}$ Trabalho apresentado pela primeira autora para obtenção do título de mestre em Zootecnia na UNESP-FCAV- Jaboticabal. Projeto financiado pelaFAPESP

2 Bolsista da FAPESP. E.mail: sfpaziani@carpa.ciagri.usp.br

${ }^{3}$ Professor do Depto de Zootecnia da FCAV - UNESP, Jaboticabal. E.mail: ttberchi@fcav.unesp.br

${ }^{4}$ Pesquisadora do CNPq
} 
sempre ocorre, como mostra o estudo de GALLOWAY et al. (1993), que indicou que as digestões de matéria orgânica (MO), fibra em detergente neutro (FDN), amido, nitrogênio e a taxa de passagem não diferiram entre tratamentos com milho grão moído e milho inteiro, mostrando não haver necessidade da moagem do grão de milho, economizando em operações de processamento.

Moer ou quebrar o grão de milho melhora aparentemente a digestibilidade do amido no trato total em comparação com o milho inteiro (GALYEAN et al., 1979, TURGEON et al., 1983), aumentando-se a degradação ruminal do alimento pelo aumento da superfície de ação dos microrganismos ruminais (PRIGGE et al., 1978). Contudo, ALCALDE (1997) avaliando milho grão inteiro seco, milho grão inteiro hidratado, milho moído grosso (19 mm) e milho moído fino $(2,5 \mathrm{~mm})$, concluiu que os graus de moagem de milho não influenciaram as digestibilidades aparentes de matéria seca (MS), proteína bruta (PB), fibra bruta (FB), fibra em detergente neutro (FDN), extrativo não nitrogenado (ENN) e energia bruta (EB), mas influenciaram as de extrato etéreo (EE) e amido. Quanto à degradação da MS, os dois tratamentos com milho inteiro tiveram menor degradação, diferindo dos outros dois com milho moído.

Com a moagem pode ocorrer maior consumo de MS e melhor conversão alimentar do que com grãos inteiros, secos ou úmidos, refletindo maior ganho de peso, o que foi concluído por SILVA et al. (1998), ao compararem grão de milho moído, grão de milho inteiro úmido e grão inteiro seco, tendo como volumoso silagem de milho.

Além do grau de moagem, outro fator que interfere na degradabilidade é a fonte protéica usada na ração. O farelo de amendoim constitui uma alternativa às fontes protéicas convencionais, como farelos de soja e algodão. Além de ter o custo por unidade de proteína menor do que os mesmos.

Sabe-se também que fontes com pouco amido e elevado teor de fibra digestível, que fornecem alto teor de energia, podem aliviar o efeito negativo do carboidrato prontamente fermentável na digestão da fibra, causado por grãos de cereais (FLECK et al., 1988). O glúten de milho-20 com teor de proteína em torno de $21 \%$ e de FDN próximo a $23 \%$ é usado como suplemento protéico-energético.

Para avaliação da digestibilidade, o método do indicador tem sido usado intensivamente por nutricionistas na determinação indireta, onde o óxido crômico $\left(\mathrm{Cr}_{2} \mathrm{O}_{3}\right)$ tem sido aceito como um dos mais confiáveis indicadores externos (CROSS et al., 1973; OLIVEIRA et al., 1991), proporcionando resultados próximos aos obtidos pelo método da coleta total (FONTES et al., 1996). Quanto ao uso da FDN indigestível como indicador, HUHTANEN et al. (1994) chegaram a dados aceitáveis, ao compararem vários indicadores internos, indicando que os componentes indigestíveis da fibra, determinados por meio de incubação ruminal, têm potencial como marcadores. Entretanto, resultados variáveis podem ser obtidos, devido a perdas de partículas de amostras de fezes e alimentos dos sacos de náilon, durante a incubação no rúmen, devendo-se evitar moer amostras finamente.

A FDN indigestível como indicador interno é provavelmente mais uniformemente distribuído na fase sólida que os indicadores externos. Mas TAMMINGA et al. (1989), ao usarem dietas ricas em concentrado (60-67\%), não obtiveram bons resultados com FDN indigestível como indicador de digestibilidade, em relação a outros. Assim, fica difícil optar por um ou outro indicador devido à grande variabilidade de resultados e contradições que existem na literatura, conforme relatado por BERCHIELLI et al. (2000).

O objetivo deste trabalho foi avaliar o $\mathrm{pH}$, amônia, digestibilidade de rações compostas por MDPS, em diferentes graus de moagem, associado a duas fontes protéicas (farelo de amendoim e glúten de milho-20), através do uso de um indicador interno (FDN indigestível) e um externo (óxido crômico); assim como avaliar a degradabilidade do MDPS, em diferentes graus de moagem.

\section{Material e métodos}

Foram utilizados 12 bovinos adultos (machos castrados), cruzados $1 / 2$ Holandês - Zebu, com idade aproximada de quatro anos, peso vivo médio inicial de $465 \mathrm{~kg}$, canulados no rúmen.

As rações experimentais foram compostas de MDPS em três graus de moagem (moídos em peneiras de 3/8, 9/16 e $3 / 4$ de polegadas, sendo fino $-0,95 \mathrm{~cm}$ de tamanho de partícula, médio - $1,43 \mathrm{~cm}$ de tamanho de partícula e grosseiro - 1,91 cm de tamanho de partícula, respectivamente), duas fontes protéicas, o farelo de amendoim ou glúten de milho-20 (ingrediente protéico composto de solúveis e das partes fibrosas do grão de milho) e feno de coastcross, formuladas segundo as normas do AGRICULTURAL AND FOOD RESEARCH COUNCIL - AFRC (1993), utilizando-se uréia para 
Tabela 1 - Composição bromatológica dos alimentos

Table 1 - Chemical composition of feeds

\begin{tabular}{|c|c|c|c|c|c|c|c|}
\hline & $\begin{array}{l}\text { MS } \\
D M\end{array}$ & $\begin{array}{l}\text { Amido } \\
\text { Starch }\end{array}$ & $\begin{array}{l}\text { PB } \\
C P\end{array}$ & $\begin{array}{l}\mathrm{EE} \\
E E\end{array}$ & $\begin{array}{l}\mathrm{MM} \\
M M\end{array}$ & $\begin{array}{l}\mathrm{FDN} \\
N D F\end{array}$ & $\begin{array}{l}\mathrm{FDA} \\
A D F\end{array}$ \\
\hline $\begin{array}{l}\mathrm{MDPS}^{1} \\
G E C\end{array}$ & 88,88 & 61,16 & 8,02 & 1,90 & 1,63 & 46,58 & 15,72 \\
\hline $\begin{array}{l}\text { Glúten de milho- } 20 \\
\text { Corn gluten feed }\end{array}$ & 83,51 & 6,38 & 28,50 & 2,20 & 8,72 & 46,53 & 12,60 \\
\hline $\begin{array}{l}\text { Farelo de amendoim } \\
\text { Peanut meal }\end{array}$ & 88,39 & 7,69 & 57,56 & 1,89 & 11,26 & 41,63 & 17,05 \\
\hline $\begin{array}{l}\text { Feno } \\
\text { Hay }\end{array}$ & 89,30 & 4,90 & 7,45 & 0,86 & 5,41 & 85,42 & 42,00 \\
\hline
\end{tabular}

${ }^{1}$ MDPS $=$ milho desintegrado com palha e sabugo $(G E C=$ ground ear corn $)$.

ajustar o nitrogênio degradável. A ingestão adotada de MS foi de $1,75 \%$ do peso vivo. As composições dos alimentos e das dietas são apresentadas nas Tabelas 1 e 2 .

Após 20 dias de adaptação dos bovinos, que receberam o alimento uma vez ao dia $(7 \mathrm{~h})$, forneceram-se $10 \mathrm{~g}$ de $\mathrm{Cr}_{2} \mathrm{O}_{3}$, via fístula ruminal, em duas doses ao dia (7 e $18 \mathrm{~h}$ ), contido em papel-filtro ( $5 \mathrm{~g}$ de $\mathrm{Cr}_{2} \mathrm{O}_{3}$ cada), durante 13 dias. Do $8^{\circ}$ ao $12^{\circ}$ dia coletaram-se fezes duas vezes ao dia, durante cinco dias consecutivos, sendo no $1^{\circ}$ dia às 7 e $17 \mathrm{~h}$, no $2^{\circ}$ às 9 e $19 \mathrm{~h}$, no $3^{\circ}$ às 11 e $22 \mathrm{~h}$, no $4^{\circ}$ às $13 \mathrm{e}$ $23 \mathrm{~h}$ e no $5^{\circ}$ dia às 15 e $1 \mathrm{~h}$. Esses horários foram estabelecidos para que se tivessem coletas com intervalos de duas horas, representando um período de 24 horas.

Do $14^{\circ}$ ao $16^{\circ}$ dia foi coletado líquido ruminal para a determinação de nitrogênio amoniacal $\left(\mathrm{N}-\mathrm{NH}_{3}\right)$ e $\mathrm{pH}$. As coletas foram realizadas a cada seis horas, representando um período de $24 \mathrm{~h}$ com intervalos de três horas, isto é, $1^{\circ}$ dia $(10,16$ e $22 \mathrm{~h})$, $2^{\mathrm{o}}$ dia $(4,7,13$ e $19 \mathrm{~h})$, e $3^{\circ}$ dia $(1 \mathrm{~h})$. $\mathrm{O} \mathrm{pH}$ foi determinado no momento da coleta e a outra parte do fluido ruminal, congelada para determinação da amônia, adicionando-se três gotas de ácido sulfúrico (PRESTON, 1986).

Sacos de náilon $(7 \times 14 \mathrm{~cm}, 50 \mu)$ foram incubados no rúmen por 1 - 2 - 3 - 4 - 6 - 24 - 48 - 72 - 96 e $120 \mathrm{~h}$. Em cada horário de incubação cada animal recebeu dois sacos de nailon: um contendo aproximadamente seis gramas de MDPS somente e outro contendo aproximadamente seis gramas de MDPS mais o concentrado protéico, respeitando os respectivos graus de moagem de MDPS e o concentrado que o animal estava recebendo na dieta.

No $8^{\circ}$ dia experimental, os sacos de náilon foram introduzidos no rúmen, sendo que antes ficaram mergulhados em água à temperatura ambiente por $1 \mathrm{~h}$, para o umidecimento do material. Os sacos foram incubados, iniciando-se pelos períodos mais longos, de modo que todos fossem retirados de uma só vez, então colocados em água gelada $\left(-4^{\circ} \mathrm{C}\right)$, para paralisar a fermentação ruminal, e lavados por três vezes em tanquinho, secos por $48 \mathrm{~h}$ a $65^{\circ} \mathrm{C}$ e pesados.

As degradabilidades potenciais (DP) foram calculadas segundo o modelo proposto por MEHREZ e ØRSKOV (1977): DP = a + b(1- e em que "a" é fração solúvel; "b" é fração insolúvel mas potencialmente degradável, e "c" é a taxa fracional de degradação da fração "b" (\%/h).

Tabela 2 - Composição das dietas (\% na base da MS) Table 2 - Diets composition (\% DM basis)

\begin{tabular}{|c|c|c|}
\hline \multirow[t]{2}{*}{$\begin{array}{l}\text { Ingrediente } \\
\text { Feed }\end{array}$} & \multicolumn{2}{|c|}{$\begin{array}{c}\% \text { (base da MS) } \\
\% \text { (DM basis) }\end{array}$} \\
\hline & $\begin{array}{l}\text { Dietas com Glúten } \\
\text { de milho- } 20 \\
\text { Diets with corn } \\
\text { gluten feed }\end{array}$ & $\begin{array}{c}\text { Dietas com farelo } \\
\text { de amendoim } \\
\text { Diets with } \\
\text { peanut meal }\end{array}$ \\
\hline $\begin{array}{l}\text { Glúten de milho- } 20 \\
\text { Corn gluten feed }\end{array}$ & 30,62 & - \\
\hline $\begin{array}{l}\text { Farelo de amendoin } \\
\text { Peanut meal }\end{array}$ & $\mathrm{m}$ & 10,63 \\
\hline $\begin{array}{l}\text { MDPS } \\
G E C\end{array}$ & 57,09 & 77,10 \\
\hline $\begin{array}{l}\text { Uréia } \\
\text { Urea }\end{array}$ & 1,00 & 1,00 \\
\hline $\begin{array}{l}\text { Feno } \\
\text { Hay }\end{array}$ & 11,29 & 11,27 \\
\hline & \multicolumn{2}{|c|}{$\begin{array}{l}\% \text { nutrientes } \\
\% \text { nutrients }\end{array}$} \\
\hline $\begin{array}{l}\mathrm{PB} \\
C P\end{array}$ & 16,90 & 15,89 \\
\hline $\begin{array}{l}\text { Amido } \\
\text { Starch }\end{array}$ & 37,42 & 48,52 \\
\hline $\begin{array}{l}\text { FDN } \\
N D F\end{array}$ & 50,48 & 49,97 \\
\hline
\end{tabular}


A soma das frações "a" e "b" é o material potencialmente degradável no rúmen. As médias das porcentagens de resíduos, nos diferentes tempos, foram comparados pelo teste de Tukey a 5\% de probabilidade.

A degradabilidade efetiva (DE) foi calculada segundo o modelo matemático proposto por ØRSKOV e McDONALD (1979): $\mathrm{DE}=\mathrm{a}+((\mathrm{b} * \mathrm{c}) /(\mathrm{c}+\mathrm{k}))$; em que k é taxa de passagem de sólidos no rúmen, sendo adotado uma taxa de passagem de $2 \%$ /hora, pois as dietas foram formuladas para a manutenção conforme sugere o AFRC (1993).

A produção fecal foi estimada a partir da concentração de $\mathrm{Cr}_{2} \mathrm{O}_{3}$ e do FDN indigestível. Para a determinação da FDN indigestível seguiu-se o mesmo procedimento utilizado no ensaio de degradação dos alimentos, descrito anteriormente, onde foram incubados aproximadamente, seis gramas de fezes ou alimentos, por 144 horas no rúmen (BERCHIELLI et al., 2000).

As fezes e os alimentos moídos $(1 \mathrm{~mm})$ foram analisados para MS, PB, EE, MM, fibra em detergente ácido (FDA), conforme SILVA (1990). A análise de amido, por intermédio do processo enzimático modificado para leitura de glicose por colorimetria (kit enzimático - Glicose Enzima Color Standard - Código BD 110-S), conforme PEREIRA e ROSSI (1995). Nas fezes foi feita análise do teor de cromo (FENTON e FENTON, 1979), e a FDN indigestível das fezes e alimentos foi determinada por modificações sugeridas por de JERACI et al. (1988), sendo adicionado $0,2 \mathrm{~mL}$ de alfa-amilase no início da digestão, por ter sido utilizado alimento rico em amido.

$\mathrm{O}$ experimento foi conduzido em dois períodos e quatro blocos, sendo dois blocos em cada período. $\mathrm{O}$ delineamento foi um fatorial ( 3 graus de moagem de milho desintegrado com palha e sabugo x 2 fontes protéicas), num total de seis tratamentos, conforme modelo matemático:

$$
\begin{gathered}
\mathrm{Y}_{\mathrm{ijkl}}=\mu+\mathrm{B}_{\mathrm{i}}+\mathrm{G}_{\mathrm{j}}+\mathrm{P}_{\mathrm{k}}+\mathrm{GP}_{\mathrm{jk}}+\mathrm{BGP}_{\mathrm{ijk}}+\mathrm{D}_{1}+ \\
\mathrm{GD}_{\mathrm{jk}}+\mathrm{PD}_{\mathrm{kl}}+\mathrm{GPD}_{\mathrm{jkl}}+\mathrm{e}_{\mathrm{ijkl}}
\end{gathered}
$$

em que: $\mathrm{Y}_{\mathrm{ijkl}}=$ valor para a característica de digestibilidade (ou degradabilidade) do alimento com

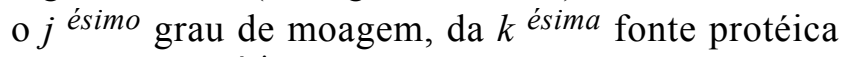
utilizando o $l$ ésimo indicador (ou tempo); $\mu$ = média geral constante comum a cada observação; $\mathrm{B}_{\mathrm{i}}=$ efeito de bloco $i(i=1 \mathrm{a} 4) ; \mathrm{G}_{\mathrm{j}}=$ efeito do grau de moagem $\mathrm{j}(\mathrm{j}=1$ a 3$) ; \mathrm{P}_{\mathrm{k}}=$ efeito da fonte protéica $\mathrm{k}(\mathrm{k}=1$ a 2$) ; \mathrm{GP}_{\mathrm{jk}}=$ interação do grau de moagem e da fonte protéica; $\mathrm{BGP}_{\mathrm{ijk}}=$ resíduo $a ; \mathrm{D}_{1}=$ efeito do indicador $l(l=1$ a 2$)$ ou então efeito do tempo para o ensaio de degradação, em que $l(l=1$ a 10$)$;
$\mathrm{GD}_{\mathrm{jk}}=$ efeito da interação do indicador (tempo) e o grau de moagem; $\mathrm{PD}_{\mathrm{kl}}=$ efeito da interação do indicador (tempo) com a fonte protéica; $\mathrm{GPD}_{\mathrm{jkl}}=$ efeito da interação entre indicador (tempo), fonte protéica e grau de moagem; $\mathrm{e}_{\mathrm{ijkl}}=$ erro residual.

Os resultados foram submetidos à análise de variância, e as médias comparadas pelo teste Tukey, a $5 \%$ de probabilidade.

\section{Resultados e Discussão}

Não houve efeito de graus de moagem do MDPS no $\mathrm{pH}$ ruminal $(\mathrm{P}>0,05)$. Nem sempre menor tamanho de partículas provoca queda no $\mathrm{pH}$ devido a uma produção rápida de ácidos. GALYEAN et al. (1979), também usando milho inteiro e moído com diferentes tamanhos de partículas, não obtiveram significância com os valores de $\mathrm{pH}$, que oscilaram entre 6,13 e 6,33, havendo apenas tendência de elevação do $\mathrm{pH}$ para os maiores tamanhos das partículas, porque à medida que se diminui o tamanho das partículas, é de se esperar que haja uma ação microbiana mais rápida, mas isso pode não ocorrer se a taxa de passagem dessas partículas for maior, portanto regulando a intensidade de fermentação, como observado por GALLOWAY et al. (1993). Também não houve efeito de graus de moagem do MDPS na concentração de amônia no fluido ruminal $(\mathrm{P}>0,05)$, mas houve efeito dos horários de coleta tanto na concentração de amônia no fluido ruminal, como no $\mathrm{pH}(\mathrm{P}<0,05)$, sendo que o $\mathrm{pH}$ e amônia começaram a declinar $3 \mathrm{~h}$ após a alimentação.

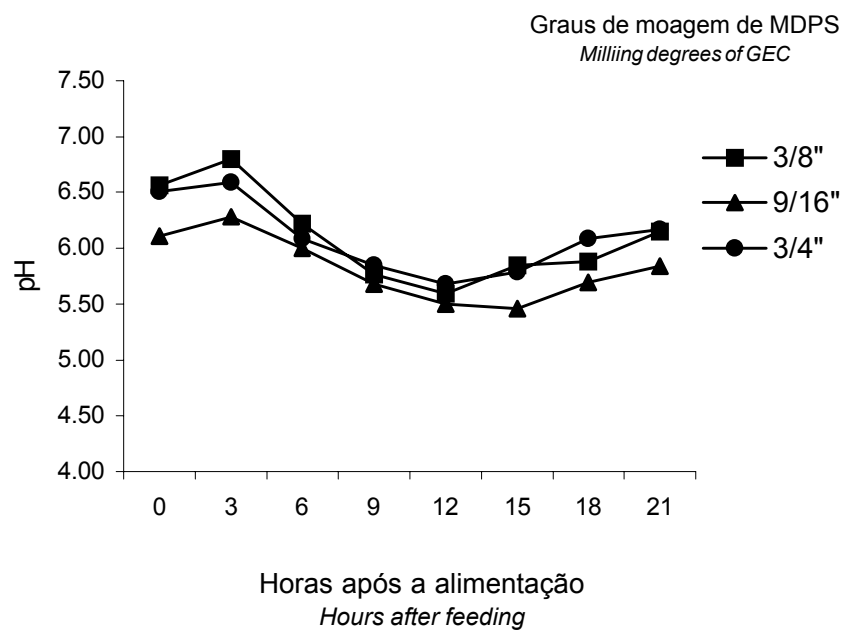

Figura 1 - Variação de $\mathrm{pH}$ em dietas com farelo de amendoim. Figure 1 - Change of $\mathrm{pH}$ in diets with peanut meal. 
Nas Figuras 1 e 2 podem ser observadas as variações no $\mathrm{pH}$ nas dietas com farelo de amendoim e glúten de milho - 20. Até aproximadamente $3 \mathrm{~h}$ após a alimentação o $\mathrm{pH}$ manteve-se alto, provavelmente, porque o alimento ainda não estava sendo fermentado e, portanto, não havia grande produção de ácidos graxos voláteis (AGV) e a salivação que ocorre no momento da ingestão contribui para manter o $\mathrm{pH}$ elevado. Três horas após a alimentação, o pH começou a declinar, com o menor valor $(5,74)$ sendo notado entre 12 e $15 \mathrm{~h}$.

Em dietas concentradas, o $\mathrm{pH}$ do fluido ruminal fica entre 5,5 e 6,5, e usualmente diminui entre meia e 4 h após a alimentação, refletindo o balanço entre as taxas de produção de $\mathrm{AGV}$, a participação do tampão saliva e a presença ou liberação de tampões ou bases do alimento. Com o processamento dos grãos, visando aumentar sua digestibilidade, há um aumento da área superficial, entretanto a maior taxa de degradação e a produção de ácidos fazem baixar o $\mathrm{pH}$ que pode paralisar a digestão da fibra da dieta, pois o $\mathrm{pH}$ ótimo para a atividade da celulase é próximo de 6 ou superior (OWENS e GOETSCH, 19,88).

Nos tratamentos com glúten de milho-20 (Figura 4), a concentração de amônia foi menor $(\mathrm{P}<0,05)$ que no tratamento com farelo de amendoim (Figura 3), dentro do grau de moagem de MDPS médio, embora no grau de moagem mais fino esta diferença não tenha sido significativa. FLECK et al. (1988) observaram maiores concentrações de amônia às $4 \mathrm{~h}$ pós suplementação com glúten de milho-20, mas às $24 \mathrm{~h}$ foi menor em comparação com o farelo de soja,

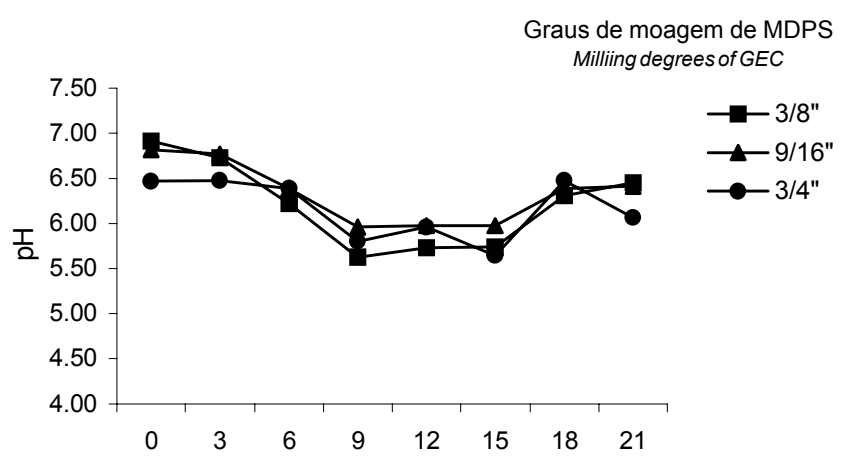

Horas após a alimentação Hours after feeding

Figura 2 - Variação de $\mathrm{pH}$ em dietas com glúten de milho-20 Figure 2 - Change of $\mathrm{pH}$ in diets with corn gluten feed indicando a extensa degradação da sua proteína devido à presença de fração solúvel.

Houve efeito da interação graus de moagem de MDPS e fonte protéica, tanto para $\mathrm{pH}$, quanto para amônia, no grau de moagem médio ( $9 / 16$ polegadas). $\mathrm{O}$ valor de $\mathrm{pH}$ com farelo de amendoim $(5,82)$, provavelmente foi menor do que com glúten de milho$20(6,34)$ porque, sendo o farelo de amendoim de maior teor protéico entrou em menor quantidade na dieta, o que elevou a proporção de MDPS (Tabela 2), que com mais grãos de milho disponíveis para a fermentação, pode ter ocasionado uma queda do $\mathrm{pH}$. Mas isto ocorreu apenas no grau de moagem de MDPS médio ( $9 / 16$ polegadas), porque embora o grau de moagem mais fino tivesse maior potencial para acidificar o meio ruminal (maior área de superfície para uma ação microbiana e fermentação mais rápida) isso não aconteceu talvez, devido a uma taxa de passagem mais rápida, evitando que as partículas de alimento fossem extensivamente fermentadas.

A maior concentração de amônia para o farelo de amendoim (Figura 3), observada no grau de moagem médio ( $9 / 16$ polegadas), pode ser atribuída ao fato de que menor $\mathrm{pH}$ diminuiu a absorção de $\mathrm{NH}_{3}$ pela parede ruminal, ficando mais disponível no ambiente ruminal, e/ou o menor $\mathrm{pH}$ pode ter prejudicado o crescimento microbiano e, com isso, a amônia disponível não foi tão utilizada pelos microrganismos. A amônia ruminal é absorvida pela parede por difusão passiva e a quantidade absorvida está positivamente relacionada à sua concentração no rúmen e depende do $\mathrm{pH}$. O N-NH 3 livre difunde-se pelas membranas

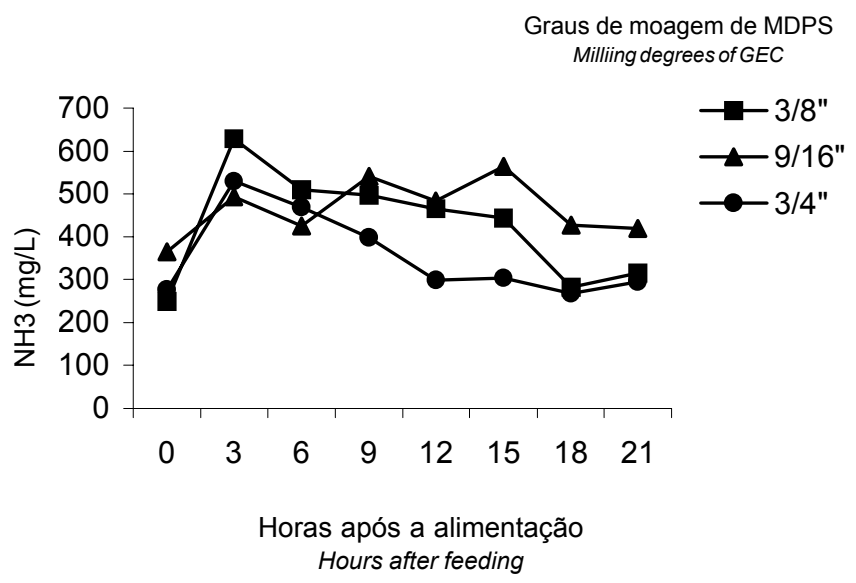

Figura 3 - Variação na concentração de amônia no fluído ruminal em dietas com farelo de amendoim.

Figure 3 - Change in ammonia concentration in rumen fluid with peanut meal. 


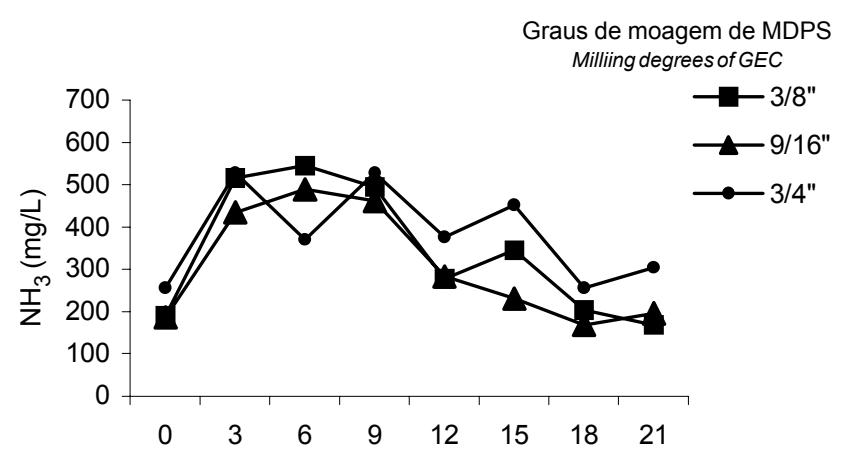

Horas após a alimentação Hours after feeding

Figura 4 - Variação na concentração de amônia no fluído ruminal em dietas com glúten de milho-20.

Figure 4 - Change in ammonia concentration in rumen fluid with corn gluten feed.

celulares muito mais rapidamente do que o N-NH 4 maiores taxas de absorção ocorrerão a $\mathrm{pH}$ mais elevados devido à maior concentração da $\mathrm{NH}_{3}$ livre. Porém, no presente trabalho não é possível afirmar até que ponto a diferença observada no $\mathrm{pH}$ entre as duas fontes protéicas, dentro do grau de moagem 9/16 polegadas, afetou a absorção de amônia e se foi esta a causa da maior concentração de amônia para este tratamento.

Não houve efeito de graus de moagem do MDPS e nem de fonte protéica para as digestibilidades aparentes de MS, FDN, FDA, EE, PB e amido, mas houve efeito do indicador, como pode ser visto na Tabela 3, em que os dados de digestibilidade calculados com $\mathrm{Cr}_{2} \mathrm{O}_{3}$ foram maiores do que os com o FDN indigestível.
Espera-se que o processamento do grão aumente a porcentagem de amido digerido tanto no rúmen como no intestino, porque a capacidade intestinal em digerir amido pode ser limitada pelo tamanho da partícula (THEURER, 1986). Também TURGEON et al. (1983) sugerem que os grãos ou partículas maiores podem apresentar limitação à adesão e colonização microbiana, se não forem reduzidos em tamanho pela mastigação, havendo, portanto, a diminuição da digestibilidade do amido com o aumento do tamanho das partículas (GALYEAN et al., 1979), mas neste trabalho isso não ocorreu.

ALCALDE (1997) comparou milho inteiro seco, milho inteiro hidratado, milho moído grosso $(19 \mathrm{~mm})$ e milho moído fino $(2,5 \mathrm{~mm})$ em rações com 30 e $60 \%$ de concentrado, tendo como volumoso o feno de capim-coastcross e observou que os graus de moagem não tiveram efeito sobre as digestibilidades de MS, PB, FB, FDN e ENN, mas diferiram para EE. Quanto à digestibilidade do amido, não foram observadas diferenças para o milho moído grosso e moído fino $(89,8$ e $90,8 \%)$, mas estes diferiram do milho inteiro $(79,3 \%)$.

Considerando que o MDPS contém aproximadamente $70 \%$ de grãos e, somando-se a ele, o concentrado protéico utilizado nas dietas deste trabalho, as dietas continham 70,6\% (glúten de milho-20) e 64,6\% (farelo de amendoim) de concentrado. Os dados de digestibilidade da $\mathrm{MS} \mathrm{com} \mathrm{Cr}_{2} \mathrm{O}_{3}$ obtidos neste trabalho $(75,57 \%)$ foram próximos aos $79,62 \%$ obtidos por CROSS et al. (1973), em dietas com 96\% de MDPS. Já FONTES et al. (1996) em dietas com $64 \%$ de MDPS e $15 \%$ feno de capim-coastcross observaram uma digestibilidade de 57,06\% com o uso de $\mathrm{Cr}_{2} \mathrm{O}_{3}$, que é um valor próximo ao obtido com a FDN indigestível $(58,61 \%)$.

Tabela 3 - Coeficientes de digestibilidade para MS, PB, FDN, FDA, amido e EE estimados com óxido crômico e FDN indigestível Table 3 - Digestibility coefficients of DM, CP, NDF, ADF, starch and EE using chromic oxide and indigestible NDF

Coeficientes de digestibilidade dos nutrientes (\%)

Digestibility coefficients of nutrients (\%)

\begin{tabular}{lcccccc} 
& Amido & MS & PB & FDN & FDA & EE \\
& Starch & $D M$ & $C P$ & $N D F$ & $A D F$ & $E E$ \\
\hline $\mathrm{Cr}_{2} \mathrm{O}_{3}$ & $97,57^{\mathrm{A}}$ & $75,57^{\mathrm{A}}$ & $73,18^{\mathrm{A}}$ & $82,71^{\mathrm{A}}$ & $53,35^{\mathrm{A}}$ & $85,08^{\mathrm{A}}$ \\
$\mathrm{Cr}_{2} \mathrm{O}_{3}$ & $95,64^{\mathrm{B}}$ & $58,61^{\mathrm{B}}$ & $58,47^{\mathrm{B}}$ & $44,16^{\mathrm{B}}$ & $27,53^{\mathrm{B}}$ & $77,23^{\mathrm{B}}$ \\
$\begin{array}{l}\text { FDNindigestível } \\
\begin{array}{l}\text { Indigestible NDF } \\
\text { CV }(\%)\end{array}\end{array}$ & & 7,15 & 7,99 & 9,08 & 24,15 & 11,26 \\
\hline
\end{tabular}

Médias seguidas pelas mesmas letras na coluna não diferem pelo teste de Tukey $(P>0,05)$.

Means follow by same letter are not different by Tukey test $(P>0.05)$.

$\mathrm{CV}$ - coeficiente de variação (CV - coefficient of variation). 
OLIVEIRA et al. (1991) com rações contendo $57,8 \%$ de MDPS obtiveram coeficientes de digestibilidade, com coleta total de fezes, de $61,81 \%$ para MS, 65,32\% para $\mathrm{PB}$ e $59,34 \%$ para FDN e são valores que estão mais coerentes com os obtidos neste trabalho com o uso da FDN indigestível do que com o uso do $\mathrm{Cr}_{2} \mathrm{O}_{3}$.

$\mathrm{Na}$ Tabela 4 são apresentados os dados referentes à degradação ruminal, onde observa-se que não houve efeito de grau de moagem na degradação potencial da MS do MDPS nos sacos de náilon $(\mathrm{P}>0,05)$. Também ALCALDE (1997) não observou diferença na degradação potencial do milho moído grosso $(19 \mathrm{~mm})$ e milho moído fino $(2,5 \mathrm{~mm})$, independente do horário de incubação, embora os grãos moídos tenham diferido dos inteiros (seco ou hidratado). Mas, houve efeito da fonte protéica, pois o MDPS que foi submetido à incubação em animais que estavam recebendo dietas com glúten de milho-20 apresentou maior degradação do que com o amendoim, indicando que o glúten de milho-20 pode promover melhores condições ruminais à ação microbiana. Este resultado pode ser devido ao fato de que no tratamento com farelo de amendoim, o menor $\mathrm{pH}$ tenha contribuído para um crescimento microbiano menos intenso e, conseqüentemente, levado à menor degradação.

Os valores da fração solúvel do presente trabalho $(11,98 \%)$ são maiores do que os $9,96 \%$ apresentados por VALADARES FILHO et al. (1990), mas menores do que o valor de $31,55 \%$ apresentado por RIBEIRO FILHO et al. (1998). Quanto à degradação efetiva, o valor apresentado por VALADARES FI-
LHO et al. (1990) foi de 32,3\%, com uma taxa de passagem de $5 \%$ /hora, e se fosse adotada taxa de passagem de $2 \%$ /hora, a degradação efetiva seria de $55,6 \%$, o que seria inferior ao aqui determinado.

Não houve efeito de grau de moagem na degradação efetiva da MS de MDPS quando incubado junto com o concentrado protéico em sacos de náilon $(\mathrm{P}>0,05)$. Mas, houve maior degradação efetiva em dietas com glúten de milho-20 do que com o farelo de amendoim (Tabela 4).

$\mathrm{Na}$ Tabela 5 são apresentados os valores das frações solúvel (a), insolúvel mas potencialmente degradável (b), taxa fracional de degradação da fração "b" (c), tempo de colonização e degradação efetiva do amido. Quando se incubou apenas MDPS nos sacos de náilon, não houve efeito do grau de moagem na degradação do amido, mas houve efeito de fonte protéica e horário de incubação. A degradação máxima ocorreu às $24 \mathrm{~h}$.

Assim como ocorreu para a degradação da MS, houve maior degradação do amido no MDPS que foi incubado em animais que estavam sendo alimentados com glúten de milho-20, talvez porque este suplemento proporcione melhores condições ruminais aos microrganismos, como discutido anteriormente.

Quanto à degradação do amido, ao se incubar MDPS com o concentrado protéico, não houve efeito de graus de moagem de MDPS e nem de fonte protéica (Tabela 5). Mas houve efeito de horários de incubação, sendo que a máxima degradação foi atingida com $24 \mathrm{~h}$ de incubação.

O processamento dos grãos visa melhorar a digestibilidade do amido, aumentando a digestão no

Tabela 4 - Fração solúvel (a), fração insolúvel mas potencialmente degradável (b), taxa fracional de degradação da fração "b" (c), coeficiente de determinação $\left(R^{2}\right)$, tempo de colonização, e degradação efetiva (DE) da matéria seca

Table 4 - Soluble (a), potentially degradable fractions (b), degradation rate (c), determination coefficient $\left(R^{2}\right)$, lag time and effective degradability (ED) dry matter

\begin{tabular}{lcccccc}
\hline $\begin{array}{l}\text { Tratamentos } \\
\text { Treatments }\end{array}$ & $\mathrm{a}$ & $\mathrm{b}$ & $\mathrm{c}$ & $\mathrm{R}^{2}$ & Tempo de & $\mathrm{DE}(\%)$ \\
& $(\%)$ & $(\%)$ & $(\%)$ & & $\begin{array}{c}\text { colonização (horas) } \\
\text { Lag time (hours) }\end{array}$ & $E D(\%)$ \\
\hline
\end{tabular}

\begin{tabular}{|c|c|c|c|c|c|c|}
\hline \multirow{4}{*}{$\begin{array}{l}\text { Amendoim } \\
\text { Peanut meal } \\
\text { Glúten de milho-20 } \\
\text { Corn gluten feed }\end{array}$} & \multicolumn{4}{|c|}{$\begin{array}{l}\text { Sacos de náilon contendo apenas MDPS } \\
\text { Ground ear corn filters bags incubation }\end{array}$} & \multirow[b]{2}{*}{1,24} & \multirow[b]{2}{*}{61,55} \\
\hline & 11,98 & 68,34 & 5,28 & 0,9938 & & \\
\hline & 11,98 & 66,93 & 6,54 & 0,9986 & 0,064 & 63,24 \\
\hline & $\begin{array}{l}\text { Sacos } \\
\text { Ground }\end{array}$ & $\begin{array}{l}\text { conten } \\
\text { vith the }\end{array}$ & $\begin{array}{l}\text { conce } \\
\text { efilter }\end{array}$ & $\begin{array}{l}\text { rotéico } \\
\text { ubation }\end{array}$ & & \\
\hline $\begin{array}{l}\text { Amendoim } \\
\text { Peanut meal }\end{array}$ & 14,22 & 67,68 & 5,99 & 0,9910 & 1,26 & 64,96 \\
\hline $\begin{array}{l}\text { Glúten de milho-20 } \\
\text { Corn gluten feed }\end{array}$ & 24,89 & 59,11 & 5,57 & 0,9998 & 0,08 & 68,38 \\
\hline
\end{tabular}


Tabela 5 - Fração solúvel (a), fração insolúvel mas potencialmente degradável (b), taxa fracional de degradação da fração "b" (c), coeficiente de determinação $\left(R^{2}\right)$, tempo de colonização e degradação efetiva (DE) do amido

Table 5 - Soluble (a), potentially degradable fractions (b), degradation rate (c), determination coefficient $\left(R^{2}\right)$, lag time and effective degradability $(E D)$ of starch

\begin{tabular}{|c|c|c|c|c|c|c|}
\hline $\begin{array}{l}\text { Tratamentos } \\
\text { Treatments }\end{array}$ & $\begin{array}{c}\text { A } \\
(\%)\end{array}$ & $\begin{array}{c}\mathrm{b} \\
(\%)\end{array}$ & $\begin{array}{c}\mathrm{c} \\
(\%)\end{array}$ & $\mathrm{R}^{2}$ & $\begin{array}{c}\text { Tempo de } \\
\text { colonização (horas) } \\
\text { Lag time (hours) }\end{array}$ & $\begin{array}{l}\mathrm{DE}(\%) \\
E D(\%)\end{array}$ \\
\hline
\end{tabular}

\begin{tabular}{|c|c|c|c|c|c|c|}
\hline \multirow{5}{*}{$\begin{array}{l}\text { Farelo de amendoim } \\
\text { Peanut meal } \\
\text { Glúten de milho-20 } \\
\text { Corn gluten feed }\end{array}$} & \multicolumn{4}{|c|}{$\begin{array}{l}\text { Sacos de náilon contendo apenas MDPS } \\
\text { Ground ear corn filters bags incubation }\end{array}$} & \multirow[b]{2}{*}{1,8} & \multirow[b]{2}{*}{76,26} \\
\hline & 44,32 & 41,07 & 7,00 & 0,8892 & & \\
\hline & 44,88 & 47,86 & 8,80 & 0,9370 & 1,1 & 83,88 \\
\hline & \multicolumn{4}{|c|}{$\begin{array}{l}\text { Sacos de náilon contendo MDPS e concentrado protéico } \\
\text { Ground ear corn with the protein source filters bags incubation }\end{array}$} & & \\
\hline & 42,48 & 42,71 & 6,10 & 0,8538 & 0,43 & 74,64 \\
\hline
\end{tabular}

rúmen, embora em termos de utilização pelo animal, pareça ser pequena a diferença entre métodos de processamento que rompem a matriz protéica do endosperma e permite acesso enzimático mais fácil aos grânulos de amido (HALE, 1973).

No presente trabalho foi notado que a fração solúvel do amido foi alta em relação aos valores encontrados na literatura, embora esses sejam variáveis. O milho possui de 65 a $68 \%$ de amido sendo de 19 a 32\% solúvel (NOCEK e TAMMINGA, 1991). PEREIRA et al. (1997), obtiveram como fração solúvel do amido $17,6 \%$.

ZEOULA et al. (1998) obtiveram 8,8\% como fração solúvel do amido do milho e 91,02\% como insolúvel mas, potencialmente degradável. A degradação efetiva foi de $41,6 \%$ a $2 \% / h$, que é bem inferior ao observado neste trabalho. Em outro trabalho, ZEOULA et al. (1997) observaram degradação efetiva de $75,51 \%$, valor esse mais próximos aos obtidos neste ensaio.

GALYEAN et al. (1981) observaram desaparecimento do amido do milho às $2 \mathrm{~h}$ de incubação como sendo $10,7 \%$, às 4 horas de $11 \%$, às 6 horas de $14,1 \%$ e às 8 horas de $13,6 \%$, que são valores bem abaixo dos observados neste trabalho.

GALYEAN et al. (1979) observaram 93,0\% de digestão ruminal do amido em milho moído $(7,94 \mathrm{~mm})$ e 70,8\% para milho inteiro, que foram valores altos e semelhantes aos dados de digestão de amido obtidos no trato total. Entre os tratamentos com diferentes tamanhos de partículas $(3,18 ; 4,76$ e 7,94 mm) não houve efeito na degradação ruminal do amido devido à similaridade entre os diâmetros médios.

GALLOWAY et al. (1993) observaram digestão ruminal de amido de milho de 78,6\%. THEURER et al. (1986) encontraram $84 \%$ para milho processado, sendo que a estrutura do amido pode ser alterada e as taxas de ataque amilolítico por microrganismos ruminais e enzimas pancreáticas podem ser melhoradas pelo processamento, ocorrendo maior fermentação ruminal do amido processado.

Pelo que foi notado neste trabalho, pode ter havido perda de partículas devido à elevada quantidade de amido solúvel que se obteve em média nos cálculos $(43,89 \%)$ e que está muito acima dos obtidos na literatura. Outra possibilidade, é que pode ter sido colocado, menor proporção de grãos de MDPS nos sacos de náilon, devido à falta de homogeneidade do material (grãos, palha e sabugo), o que teria sido computado como amido degradado em relação ao amido do alimento.

\section{Conclusões}

Os diferentes graus de moagem de MDPS adotados neste trabalho $(3 / 8,9 / 16$ e $3 / 4$ polegadas $)$ não diferiram em relação ao $\mathrm{pH}$ e à concentração de amônia no fluido ruminal, assim como quanto à digestibilidade e degradabilidade dos nutrientes da rações portanto, pode-se adotar um grau de moagem mais grosseiro economizando-se energia no seu processamento. 


\section{Referências Bibliográficas}

AGRICULTURAL AND FOOD RESEARCH COUNCIL AFRC. 1993. Technical committee on responses to nutrients: energy and protein requirements of ruminants. Wallingford: Commonwealth Agricultural Bureaux International. 159p.

ALCALDE, C.R. Avaliação da graus de moagem ou hidratação do milho através da digestibilidade aparente, degradação ruminal e desempenho de bovinos. Jaboticabal, SP:FCAV, 1997. 111p. Tese (Doutorado em Zootecnia). Faculdade de Ciências Agrárias e Veterinárias - Universidade Estadual Paulista, 1997.

BERCHIELLI, T.T., ANDRADE, P., FURLAN, C.L. 2000. Avaliação de indicadores internos em ensaios de digestibilidade. Rev. Bras. Zootec., 29(3):831-834.

CROSS, D.L., BOLING, J.A., BRADLEY, N.W. 1973. Chromic oxide and crude protein excretion in the bovine as influenced by water restriction. J. Anim. Sci., 36(5):982-985.

FENTON, T.W., FENTON, M. 1979. An improved procedure for the determination of chromic oxide in feed and feces. Can. J. Anim. Sci., 59 (3): 631-634.

FLECK, A.T., LUSBY, K.S., OWENS, F.N., et al. 1988. Effects of corn gluten feed on forage intake, digestibility and ruminal parameters of cattle fed native grass hay. J. Anim. Sci., 66(2):750-757.

FONTES, C.A.A., OLIVEIRA, M.A.T., LANA, R.P. et al. 1996. Avaliação de indicadores na determinação da digestibilidade em novilhos. R. Soc. Bras. Zootec., 25(3):529-531.

GALLOWAY, D.L., GOETSCH, A. L., FORSTER JR, L.A. et al. 1993. Digestion, feed intake and live weight gain by cattle consuming bermudagrass and supplemented with different grains. J. Anim. Sci., 71(5):1288-1297.

GALYEAN, M.L., WAGNER, D.G., OWENS, F.N. 1979. Corn particle size and extent of digestion by steers. J. Anim. Sci., 49(1):204-210.

GALYEAN, M.L., WAGNER, D.G., OWENS, F.N. 1981. Dry matter and starch disappearance of corn and sorghum as influenced by particle size and processing. J. Dairy Sci., 64(9): 1804-1809.

HALE, W.H. 1973. Influence of processing on the utilization of grains (starch) by ruminants. J. Anim. Sci., 37(4):1075-1080.

HUHTANEN, P., KAUSTELL, K., JAAKKOLA, S. 1994. The use of internal markers to predict total digestibility and duodenal flow of nutrients in cattle given six different diets. Anim. Feed Sci. Technol., 48(1):211-227.

JERACI, J.L., HERNANDEZ, T., ROBERTSON, J.B. et al. 1988. New and improved procedure for neutral detergent fiber. J. Anim. Sci., 66 (1): 351 (Abstract)

MEHREZ, A.Z., ØRSKOV, E.R. 1977. A study of the artificial fiber bag technique for determining the digestibility of feeds in the rumen. J. Agric. Sci., 88(3): 645-665.

NOCEK, J.E., TAMMINGA, S. 1991. Site of digestion of starch in the gastrointestinal tract of dairy cows and its effects on milk yield and composition. J. Dairy Sci., 74(10):3598-3629.

OLIVEIRA, R.F.M., FONTES, C.A.A., SILVA, J.F.C. et al. 1991. Estudo da recuperação fecal de $\mathrm{Cr}_{2} \mathrm{O}_{3}$ e dos indicadores internos CIA, CIDA e lignina em períodos de coleta de dois a sete dias, em bovinos. R. Soc. Bras. Zootec., 20(5):522-531.

ØRSKOV, E.R., Mc DONALD, I. 1979. The estimation of protein degradability in the rumen from incubation measurements weighted according rate of passage. J. Agric. Sci., 92(4):499-503.
OWENS, F.N., GOETSCH, A L. 1988. Ruminal fermentation. In: CHURCH, D.C. The ruminant animal: digestive physiology and nutrition. New Jersey:Prentice Hall: Englewood Cliffs. p.145-171.

PEREIRA, J.R.A., BOSE, M.L.V., BOIN, C. 1997. Avaliação das sub-frações dos carboidratos e das proteínas usando a metodologia do CNCPS e in situ, com bovinos da raça Nelore. 2. Milho e farelo de algodão. R. Soc. Bras. Zootec., 26(4):838-843.

PEREIRA, J.R.A., ROSSI JR., P. 1995. Manual prático de avaliação nutricional de alimentos. Piracicaba: FEALQ. 25p.

PRESTON, T.R. 1986. Better utilization of crops residues and by products in animal feeding: research guidelines. 2. A practical manual for research workers. S.L., Food And Agriculture Organization of the United Nation. 154p.

PRIGGE, E.C., GALYEAN, M.L., OWENS, F.N. et al. 1978. Microbial protein synthesis in steers fed processed corn rations. J. Anim. Sci., 26(1):249-254.

RIBEIRO FILHO, E., PAIVA, P.C.A, REZENDE, C.A P. et al. Cinética da digestão ruminal da casca de café em vacas da raça Holandesa. In: REUNIÃO ANUAL DA SOCIEDADE BRASILEIRA DE ZOTECNIA, 35, 1998a, Botucatu. Anais... Botucatu: SBZ, 1998. p.555-557.

SILVA, D.J. 1990. Análise de alimentos: métodos químicos e biológicos. 2.ed. Viçosa, MG: UFV. 165p.

SILVA, J.M., THIAGO, L.R.L.S., FEIJÓ, G.L.D. et al. Efeito do processamento do grão de milho na engorda de bovinos confinados. In: REUNIÃO ANUAL DA SOCIEDADE BRASILEIRA DE ZOOTECNIA, 35, 1998, Botucatu. Anais... Botucatu:SBZ, 1998. p.242-244.

TAMMINGA, S., ROBINSON, P.H., BOER, H. 1989. Feed components as internal markers in digestion studies with dairy cows. Anim. Feed Sci. Technol., 27 (1): 49-57.

THEURER, C.B. 1986. Grain processing effects on starch utilization by ruminants. J. Anim. Sci., 63 (5): 1649-1662.

TURGEON JR., O.A., BRINK, D.R., BRITTON, R.A. 1983. Corn particle size mixtures, roughage level and starch utilization in finishing steer diets. J. Anim. Sci., 57(3):739-749.

VALADARES FILHO, S.C., SILVA, J.F.C., LEÃO, M.I. et al. 1990. Degradabilidade "in situ” da matéria seca e proteína bruta de vários alimentos em vacas em lactação. R. Soc. Bras. Zootec., 19(6):512-522.

ZEOULA, L.M., ALCALDE, C.R., FREGADOLLI, F. et al. Degradação ruminal de grãos de cereais e raspa de mandioca amassados. In: REUNIÃO ANUAL DA SOCIEDADE BRASILEIRA DE ZOOTECNIA, 35, 1998, Botucatu. Anais... Botucatu: SBZ. 1998. p.35-37.

ZEOULA, L.M., MARTINS, A.S, SANTOS, G. et al. Estudo da cinética da degradação do amido de diferentes alimentos energéticos. In: REUNIÃO ANUAL DA SOCIEDADE BRASILEIRA DE ZOOTECNIA, 34, 1997, Juiz de Fora. Anais... Juiz de Fora: SBZ, 1997. p.127-130. 